\title{
The Judicial Control Enforced over the Formation of the Arbitration Body in Pursuant to the Jordanian Arbitration Law
}

\author{
Maher J. Aljaber ${ }^{1}$, Murad M. Al-Shnaikat ${ }^{1} \&$ Asma M. Al-Raqqad ${ }^{1}$ \\ ${ }^{1}$ Faculty of Law, Al-Balqa Applied University, Al-Salt, Jordan \\ Correspondence: Maher Aljaber, Department of Public and Private Law, Faculty of Law, Al-Balqa Applied \\ University, Al-Salt, Jordan. Tel: 96-27-9534-3700. E-mail: maheraljaber@bau.edu.jo
}

Received: February 11, 2020

Accepted: May 14, $2020 \quad$ Online Published: May 30, 2020

doi:10.5539/jpl.v13n2p250

URL: https://doi.org/10.5539/jpl.v13n2p250

\begin{abstract}
Nowadays, arbitration has been receiving much attention. Such attention can be manifested through enacting national legislations and international agreements to regulate it. Such legislations and agreements address the way of choosing arbitrators and the conditions of obtaining membership in the arbitration body. The judicial control is enforced on the arbitration process, because the judiciary is considered the one that has jurisdiction over the settlement of disputes. Such control is enforced to ensure that the arbitral awards are unbiased and impartial. It's enforced to reach a sound arbitral award that is free from faults. It's enforced to ensure that nothing shall affect the formation of the arbitration body and its arbitral award.

The present study aimed to explore the extent of control enforced by judiciary on the appointment and dismissal of arbitrators and the consideration of the assignment of arbitrators as void. It aimed to identify the extent and limits of this control. Thus, it aimed to identify the way in which the Jordanian legislator regulated these matters. The researchers of the present study adopted an analytical approach to analyze the legislative texts listed in the Jordanian arbitration act and the comparative acts. They also analyzed the relevant judgments issued by the Jordanian court of cassation.
\end{abstract}

Keywords: arbitration, arbitrator, ad-hoc arbitration, institutional arbitration

\section{Introduction}

Due to experiencing globalism, the world has become a small village. That affected various aspects of life; political, social, moral and economic aspects. That's because countries have become open to each other. Today, one can contact any one at any place due to the development of ICT. Such development affected economic areas. For instance, very significant business transactions can be conducted today through using ICT. Thus, people today can export and import products without being concerned about experiencing late delivery. Hence, people can ensure that their products will not be damaged due to late delivery. The creation of ICT encouraged people to conduct transactions with foreign clients through concluding contracts. Through contract, parties can agree to various contractual issues, such as: choosing the place of concluding the contract, the place of implementing the contract and the currency. Through contracts, parties can agree to various preferences in order to implement the contract in the best manner.

A dispute may arise between the parties of the contract about the implementation of the contract. In case the parties' nationalities differ, the parties may hesitate about going to courts. That's because such parties want to avoid the enforcement of the provisions of the local laws. Such parties want to avoid that, because they don't have knowledge about these provisions, or because these provisions do not take into consideration the customs of international business.

Therefore, many disputed parties seek settling their contractual disputes through arbitration. That's because the arbitration procedures are usually taken fast and require less cost. The disputed parties seek arbitration to avoid going to courts which may take many years to settle a dispute. In addition, disputed parties seek arbitration because settling some cases requires having a person with expertise in a specific field to settle the dispute. Such cases includes: the cases related to banks, insurance, construction and trademarks, and international cases (Al-Dahleh, 2001, p. 5).

Arbitration is derived from the verb arbitrate. In language, it refers to the processes of resorting to one to obtain a 
decision from him/her to settle a certain dispute. The one who's responsible for the arbitration process is called the arbitrator. The arbitrator refers to a person that people choose to settle a dispute between them (Shafiq, 1970, p. 14).

In jurisprudence, the term (arbitration) refers to the process that is performed in order to settle the contractual disputes between disputed parties. This process is represented in identifying the dispute before person(s) (i.e. arbitrator(s)) in order to avoid going to court (Al-Mu'nes, 1977, p. 10). Robert defines (arbitration) as (a special judicial system that aims at settling a specific dispute which settlement falls under the jurisdiction of the judiciary. Conducting the arbitration process is assigned to specific people (Shafiq, 1970, p. 14)). Sharia regulates the arbitration process and addresses various issues related to arbitration. Thus, similar to the publications of foreign authors, Sharia provides adequate information about arbitration. Fiqh defines arbitration as an agreement concluded between two parties or more in order to select a person to settle a dispute between them in accordance with the provisions of Shariah. Al-Mawerdy defines arbitration as an approach adopted by the disputed parties. According to Al-Mawerdy, through adopting this approach, these parties select a person to settle the dispute existing between them. The Muslim scholars specialized in modern jurisdiction define arbitration as a mean recognized by many countries. According to the latter scholars, this mean is used for settling disputes and regulated by the state. The state is responsible for identifying the cases in which the parties are permitted to seek arbitration and the cases in which the parties are not permitted to seek arbitration. It's also responsible for identifying the cases in which the parties are obliged to seek arbitration (Madkour, 1999, p. 398).

Shariah aims at protecting people's interests or preventing damage. Thus, under Shariah, seeking arbitration is permitted. For instance, arbitration aims at protecting the disputed parties' interests. These interests are represented in creating amicable relationships between the parties and restoring rights to the ones who are entitled. Thus, seeking arbitration shall enable people to carry out transactions in accordance with the agreement. It shall enforce justice. There are proofs indicating that arbitration is permitted under Shariah. For instance, a verse in Quran states the following: (If ye fear a breach between them twain, appoint (two) arbiters, one from his family, and the other from hers; if they wish for peace, Allah will cause their reconciliation: For Allah hath full knowledge, and is acquainted with all things). ${ }^{1}$ There is another verse in Quran that states the following: (But no, by the Lord, they can have no (real) Faith, until they make thee judge in all disputes between them, and find in their souls no resistance against Thy decisions, but accept them with the fullest conviction). ${ }^{2}$

There are proofs in Sunah that indicate that arbitration is permitted. For example, Yazid bin Al-Meqdam bin Meshre' bin Hani Al-Harethy stated that his father; Al-Meqdam bin Meshre' bin Hani Al-Harethy; stated that Prophet Mohammad visited a group of people. One of those people was called Abu Al-Hakam (i.e. arbitrator). The Prophet told that man: (Allah is the arbitrator and the one who shall rule. So, why would you let people call you Abu Al-Hakam (i.e. arbitrator)?. That man said: (No. If a dispute arises between people, the disputed parties come to me to issue a judgment for settling their dispute). The Prophet said: (Doing that is a very good deed). He asked the man: (How many sons do you have?). The man said: (My children are: Sharih, Abdullah and Muslim bani Hani). The Prophet asked: (Who's the oldest son?). The man said: (Sharih). The Prophet said: (Then, I shall call you Abu Sharih). He wished that man and his son to be blessed by Allah (Al-Nesa'I, 1964, p. 199). Thus, all the companions of Prophet Mohammad suggested that it's permitted to seek arbitration. They used arbitration as a method for settling many disputes between Muslims in various issues. For example, Zayd bin Thabet was the arbitrator who settled the dispute between Omar bin Al-Khatab and Obai bin Ka'b (Al-Zayla'I, 1315, p. 193).

Today, arbitration in international business transaction is very important. For instance, it's rare to find an international contract that doesn't include a clause that regulates the settlement of contractual disputes. In this context, arbitration refers to optional arbitration. Through optional arbitration, the parties voluntarily agree to settle the contractual dispute that (may arise/ or have already arisen) between them through seeking arbitration. The parties agree on that, because they find that arbitration fits with the requirements and nature of international business. For instance, arbitration is considered a method that settles disputes quickly, saves costs, and requires taking less procedures than courts.

Arbitration in international business transaction is very important. That's because arbitration doesn't have one judicial body responsible for hearing the case involving a dispute derived from an international business contract. Arbitration is very important because there aren't standard legal rules that regulate the settlement of the dispute derived from an international business contract through arbitration. Parties don't prefer settling their dispute before national courts, because they fear enforcing the provisions of the national laws. Parties fear that, because

\footnotetext{
${ }^{1}$ Al-Nisa'Surah, verse No.35.

${ }^{2}$ Al-Nisa'Surah, verse No.65.
} 
they don't have knowledge about these provisions, or because these provisions do not take into consideration the customs of international business (Sami, 1997, p. 23).

Arbitration may be ad hoc arbitration which is practiced by one arbitrator or several ones. The disputed parties are responsible for choosing the arbitrators and their duties and the place of performing the arbitrating process. They are responsible for choosing the law to be applicable on the case and the arbitration procedures. There is another type of arbitration (i.e. institutional arbitration). Through the latter arbitration, the parties agree on assigning their arbitration process to a specific institution. This institution shall be responsible for choosing the arbitrators and identifying their responsibilities.

The arbitration body plays a significant role in the arbitration process. It performs a significant judicial function that differs from the judge's judicial function. It's not required to assign an arbitrator who has studied law. The arbitrator may be an expert in economy, engineering, or international business. Today, arbitration is considered very significant. Thus, it has been receiving much attention by governments. Due to its significance, governments took several measures to ensure that the arbitration process shall be correct and valid. For instance, it's required to enforce judicial control over the arbitration process, and the formation of the arbitration body. Such control is enforced to ensure that the arbitral awards shall be unbiased and impartial. In addition, the judiciary may dismiss the arbitrators or consider their assignment as void in case there are legal reasons that require doing so.

\subsection{Statement of the Problem and the Study's Approach}

The present study aimed at examining the mechanism implemented for forming the arbitration body in the ad hoc arbitration and institutional arbitration. It aimed at examining the extent of the judicial control enforced over the implementation of this mechanism. This control is enforced to ensure that the arbitral award is recognized and implemented. To meet the study's goals, a descriptive analytical approach and a comparative approach are adopted. Through adopting these approaches, the researchers analyzed the legislative texts listed in the Jordanian arbitration act. The researchers also compared the latter texts with the texts listed in comparative acts. They reviewed the relevant judgments issued by the Jordanian court of cassation. In short, the present study addresses the mechanism implemented for forming the arbitration body in the ad hoc arbitration and the institutional arbitration. It also addresses the conditions of choosing arbitrators (part one). It addresses the extent of the judicial control enforced over the process of choosing arbitrators. It addresses the parties' right to appeal against such choice. It addresses the dismissal of the arbitrators and the consideration of the arbitrators' assignment as void (part two).

\section{The Formation of the Arbitration Body}

If both parties agreed on seeking arbitration, they shall not go to court to settle their dispute. That applies in case parties agreed on that through listing a clause in their original contract before the occurrence of the dispute. It also applies in case the parties agreed to do that through concluding an arbitration contract after the occurrence of the dispute. ${ }^{3}$ The parties may agree on seeking ad hoc arbitration. Through ad hoc arbitration, the parties shall agree on all the arbitration-related details. For instance, through it, the parties shall agree on choosing the arbitrators. They may choose the arbitrators by themselves or delegate a third party to do that. The parties may agree on performing institutional arbitration. Through the latter arbitration, the parties agree on assigning their arbitration process to a specific institution that is specialized in arbitration-related issues. Thus, this institution shall be responsible for taking all the arbitration-related procedures, including the procedures related to choosing arbitrators.

In this regard, the following question may arise: (How is the arbitration body formed?) It can be noticed that national legislations regulate this matter due to the significant impact of this matter on the outcomes of the arbitration process. Under national legislations, there are three main mechanisms for forming the arbitration body; 1- Formation of the arbitration body by the parties themselves. 2- Formation of the arbitration body by the court 3- Forming this body by a body or an institution in pursuant to a delegation made by the parties. Further information about that is presented below:

\footnotetext{
${ }^{3}$ An arbitration clause may be listed in the original contract. It suggests that any potential dispute in the future shall be settled through arbitration. It may be within the contract or attached to it. However, the parties may conclude an arbitration contract after the occurrence of the dispute. This contract suggests that the dispute shall be settled through arbitration.
} 


\subsection{Choosing Arbitrators in the Ad Hoc Arbitration ${ }^{4}$}

Under national legislations and international agreements, parties are entitled to choose their own arbitrators, because they have the right to enforce their wills. That can be manifested through the amended Jordanian arbitration act of 2018. The latter act includes the following text:

“A) Both parties are entitled to choose arbitrators and the way of choosing them. If they didn't reach an agreement on this matter, the following measures shall be taken:

1) If the arbitration body consists from one member, the judge who has jurisdiction shall be responsible for choosing the arbitrator.

2) If the arbitration body consists from three arbitrators, each party shall be responsible for choosing one arbitrator. The third arbitrator must be chosen by the two arbitrators mutually. The judge who has jurisdiction shall be responsible for choosing the arbitrator. That applies in case one of the parties didn't choose his arbitrator within the 15 days following the date on which he received a notification by the other party. It also applies in case the two arbitrators didn't choose the third arbitrator within the 15 days following the date on which the last arbitrator was chosen. The judge shall do that upon the request of any of the parties. The arbitration body shall be headed by the arbitrator who was chosen by the two arbitrators mutually or by the judge who has jurisdiction.

B) If there are three parties or more, they shall agree on the number of arbitrators and the way of choosing them and choosing the head of the arbitration body. In case the parties didn't reach an agreement on that, the following procedures shall be taken:

1) In case the parties agreed on the number of arbitrators, but didn't agree on the way of choosing the head of the arbitration body, the head shall be chosen through obtaining the consensus of the members of the selected arbitrators. In case the arbitration body couldn't choose the head through this way, the judge who has jurisdiction shall be responsible for assigning the head upon the request of the disputed parties.

2) In case the parties agreed on the number of arbitrators, but didn't agree on the way of choosing the arbitrators, the judge who has jurisdiction shall be responsible for assigning the arbitrators in pursuant to the number that the parties agreed on. The judge shall be responsible for assigning the head of the body from those arbitrators.

3) If the parties didn't agree on the number of the arbitrators and the way of choosing the arbitrators, the arbitration body shall be consisting from three arbitrators. The judge who has jurisdiction shall be responsible for assigning the arbitrators and the head of the body from those arbitrators.

C) The judge who has jurisdiction may be responsible for carrying out the procedures after hearing the statement made by the other party. That applies if any of the parties violated the agreed upon procedures of choosing the arbitrators. It applies if the parties didn't agree on the way of carrying such procedures. It applies if the appointed arbitrators didn't agree on something they must agree on. It applies if a delegated person failed to do something assigned to him in this regard.

D) When choosing the arbitrator by the judge who has jurisdiction, the judge must meet the conditions set by the law and the conditions that both parties agreed on. The judge must make his decision quickly after hearing the statement made by the other party". 5

Through these legislative texts, it can be found that there are two mechanisms for assigning the arbitrators or forming the arbitration body. Before exploring these mechanisms in depth, the researchers must identify first the principles that regulate the formation of the arbitration body. The first principle is represented in protecting the disputed parties' right in enforcing their will. This principle is considered the most significant principle. In case the parties agreed on a specific method to choose the arbitrators, these parties must implement this method. The second principle is represented in achieving equality between the disputed parties when forming the arbitration body. To illustrate more, none of the parties can have more powers than the other party in terms of choosing arbitrators. For instance, it's not permitted for any party to choose all the arbitrators by himself only. That applies, unless both parties agree earlier on doing that (Muneer, 1995, p. 115). In this regard, one may ask: (How is the arbitration body formed?) Further information about that is presented below from the Jordanian legislator's perspective:

\footnotetext{
${ }^{4}$ The ad hoc arbitration refers to the arbitration through which the parties agree to all the arbitration procedures without seeking the help of an arbitration body.

${ }^{5}$ The same is stipulated through article 17 of the Egyptian arbitration act of 1994. The same is stipulated through article 11 of UNCITRAL model law on international commercial arbitration issued by the United Nations Commission on International Trade Law. The same is stipulated through article 6 and 7 of the UNCITRAL arbitration rules issued by the United Nations Commission on International Trade Law.
} 


\subsubsection{Formation of the Arbitration Body by Both Parties}

The agreement of both parties in ad hoc arbitration suggests that no institution shall be involved. Thus, in this case, the parties shall be responsible for choosing the members of the arbitration body. That applies whether the arbitration body shall be consisting from one arbitrator, three arbitrators or more. That applies provided that the number of the members of the arbitration body is odd. Each party shall be responsible for choosing one arbitrator After that, the selected arbitrators shall be responsible for choosing the third arbitrator. Under the amended Jordanian arbitration act of 1952, the third arbitrator is called the ruling arbitrator. The third arbitrator shall serve as the head of the arbitration body.

If both parties agreed on the way of choosing the arbitrators, they must also agree on the way of handling the problems associated with choosing them. Such problems may include the ones listed in article 16/ paragraph $1 /$ item 2 of the Jordanian arbitration act. The parties should identify the solution adopted in each potential problem (Sami, 1997, p. 138). Such solutions may include: appointing a person or an authority that is responsible for choosing arbitrators, in case there's a disagreement about the appointment of arbitrators.

The parties have the right to choose members of the arbitration body. In case there is a need to form a new arbitration body, the parties have the right to choose the members of the new arbitration body. They also have the right to choose a new member in case there is a need to replace one of the members of the arbitration body with a new member. That is stipulated through article 20 of the Jordanian arbitration act. The latter article states the following: (The function of the arbitrator may come to an end. For instance, the arbitrator may be dismissed. He may step down from his position, die or become disabled. The function of the arbitrator may come to an end for any other reason. In such a case, a new arbitrator must be chosen instead of that arbitrator. That must be done in accordance with the procedures of choosing the arbitrator replacing the arbitrator whose function came to an end) ${ }^{6}$

Despite that, the parties' right to choose the arbitrators is regulated by a condition (i.e. achieving equality between the parties in term of exercising the right to appoint arbitrators). For instance, it's not permitted for any party to choose all the arbitrators by himself only. Furthermore, it's not permitted for any party to choose more arbitrators than the other party. That shall apply unless there's an agreement that states otherwise.

Despite that, it may be difficult to adopt the latter principle of equality. That occurs in case the contract is concluded between three parties and states that the dispute shall be settled through arbitration. In case there are two plaintiffs, would the equality principle be enforced through letting the claimant appoint an arbitrator, and letting each plaintiff appoint an arbitrator? Or would the equality principle be enforced through letting the claimant appoint an arbitrator, and letting the two plaintiffs appoint one arbitrator, in order for the selected arbitrator to appoint the third arbitrator?

The Jordanian law doesn't address this case. However, in the latter case, most of the French jurists suggest that the claimant shall appoint an arbitrator and the two plaintiffs shall appoint one arbitrator and then, the appointed arbitrators shall choose the third arbitrator (Al-Jamal \& Okashi, 1998, p. 581). The party may choose the arbitrator by himself or let his delegated person choose the arbitrator. He can delegate a person to exercise this right, because this right is not considered a personal right. The attorney may be delegated through the contract to assign an arbitrator in coordination with the other part. In this case, the attorney may assign an arbitrator through identifying the name or position of the selected arbitrator in specific. In case the attorney wasn't delegated to do so through the contract, the concerned party may delegate the attorney through concluding a special agreement (Abu Al-Wafa, 1988, p. 49).

The process of assigning arbitrators may be performed through identifying the name or position of the chosen arbitrators. However, in case the arbitrator gets chosen through identifying his position, the position must be clearly referring to the ID of the concerned arbitrator. For instance, when saying (the President of the Bar Association or the President of the Engineers Association), such a position can clearly identify the arbitrator's ID. However, in case the agreement includes a position that many people hold, the agreement shall be void. Such positions may include: engineer, or farmer (Al-Jamal \& Okashi, 1998, p. 586).

A party may choose an arbitrator based on his position. For example, he may choose the dean of the faculty of law at the University of Jordan to be his arbitrator and the position may be vacant at the time of making such choice. In this case, the officer in charge shall be the arbitrator, provided that the party has made this choice based on the arbitrator's position. However, a party may choose an arbitrator through identifying his name in

\footnotetext{
${ }^{6}$ The same is stipulated through article 21 of the Egyptian arbitration act of 1994. Article 15 of UNCITRAL model law on international commercial arbitration of 1985 .
} 
specific without taking that arbitrator's position into consideration. In the latter case, the chosen person must be appointed even if he has resigned from his position at work or his services were terminated at work (Al-Tahyawi, 2003. P. 195).

Each party may choose his arbitrator and both parties shall let the appointed arbitrators choose the third arbitrator. In short, choosing the third arbitrator shall occur through delegating the two selected arbitrators to do that. Both parties may delegate a person to choose the arbitrator. Such delegation can be made through identifying the name or the position of this delegated person in specific. That is permitted whether the delegated person is a natural or a moral person. Thus, in case this delegated person chose an arbitrator, his choice shall be considered valid and accepted (Al-Jamal \& Okashi, 1998, p. 586).

Thus, if the parties chose the arbitrators in this manner, their choices shall be considered valid and accepted, because both parties have the right to enforce their wills. Enforcing their wills is a major principle that regulates the process of choosing arbitrators. However, what would the solution be in case the arbitration agreement permits the parties to choose their arbitrators, and the parties didn't want to choose their arbitrators on this basis?

\subsubsection{Formation of the Arbitration Body by the Court}

One of the methods of choosing arbitrators is represented in selecting them by the court. That is stipulated through article 16 of the Jordanian arbitration act. That's discussed later.

\subsection{Choosing Arbitrators under the Institutional Arbitration System}

The disputed parties prefer assigning a specialized institution for settling the dispute and regulating the arbitration process. That's because the disputes parties may want to facilitate the process of taking the arbitration procedures. Such procedures include choosing arbitrators. Through assigning a specialized institution, it's not necessary for the parties to agree on the procedures of choosing arbitrators. That's because the procedures determined by the institution are the ones to be taken. Through this study, the researchers aim to identify the measures adopted by very famous arbitration institution in the field of international business (i.e. the International Chamber of Commerce $;^{7}$ in Paris). Through analyzing the legislative texts listed in the code of the

\footnotetext{
${ }^{7}$ The International Chamber of Commerce was established in 1919 in Paris by the Minister of Commerce; Eitenne Clemeriel. The arbitration court affiliated with the latter chamber was established in 1923. The arbitration rules of the latter chamber -that are considered applicable today- were amended in 1998. These rules became in force since 1, January, 1998. The International Chamber of Commerce is considered the most famous arbitration institution. For instance, about 300 arbitration cases are filed each year to the latter chamber. Article 7 of the arbitration rules of the International Chamber of Commerce states: (Unless the parties have agreed to something else, the arbitration body shall be formed in pursuant to articles 12 and 13-:

Article 12: The formation of the arbitration body:

1) Disputes shall be settled by one arbitrator or three ones

2) In case the parties didn't reach an agreement on the number of arbitrators, the court shall form a single-member arbitration body. That applies, unless the nature of the dispute requires forming a three-member arbitration body. In this case, the claimant must assign an arbitrator within 15 days following the day on which he was notified about the court decision. The plaintiff must assign an arbitrator within 15 days following the day on which he was notified about the court decision. In case any of them didn't assign an arbitrator, the court shall assign an arbitrator on behalf of that party A single-member arbitration body

3) If the parties agreed to settle the dispute through forming a single-member arbitration body, they must identify the name of the selected arbitrator in order to be approved. The court shall assign the member of the single-member arbitration body, in case the parties didn't name the member of the single-member arbitration body within 30 days following the day on which the plaintiff was notified by the claimant. In addition, the court shall also assign this member, in case the parties didn't name the selected arbitrator within the additional duration provided by the secretariat-general

A three-member arbitration body

4) The parties may agree on forming a three-member arbitration body. In this case, each party shall identify the name of the selected arbitrator in the request. In case none of the parties identified the name of his arbitrator, the court shall be responsible for assigning the arbitrators

5) If the dispute must be settled by a three-member arbitration body, the court shall be responsible for assigning the third arbitrator who shall head the arbitration body. That applies unless the parties have agreed on taking specific procedures to select the third arbitrator. In this case, the name of the selected third arbitrator must be approved in pursuant to article 13. In case such agreed upon procedures weren't taken within 30 days following the day on which the two arbitrators were approved, or the day on which the court assigned the two arbitrators, the court shall assign the third arbitrator. The court shall assign the third arbitrator in case the parties didn't' identify the name of the third arbitrator within the duration specified by the parties or the court.

6) If there are several claimants or plaintiffs and the arbitration body must be a three-member arbitration body, the claimants must mutually choose one arbitrator and the plaintiffs must mutually choose one arbitrator. The selected arbitrators shall be approved in pursuant to article 13
} 
International Chamber of Commerce, it can be concluded that there are two mechanisms for forming the arbitration body. These mechanisms are listed below

\subsubsection{Formation of the Arbitration Body by the Two Parties}

The code of the International Chamber of Commerce grants the parties the right to choose the members of the arbitration body. For instance, if the parties agreed on implementing a specific mechanism for forming the arbitration body, the court must implement the agreed upon mechanism. That applies even if the agreed upon mechanism differs from the mechanism of the latter chamber. That should be done without taking the rules of the chamber into consideration. Thus, the parties have the right to choose the arbitration body which may consist from one member, three members or more. If both parties agreed on having one member only, both parties shall choose the arbitrator mutually. The arbitrator may be a natural or a moral person.

The parties may decide to have a three-member arbitration body. In this case, each party shall choose one arbitrator. The third arbitrator may be chosen by the court or by another party delegated by the two parties. That should be done in accordance with the code of the latter chamber. The delegated party -who is responsible for choosing the third arbitrator - must take into consideration the nationality of the arbitrator. To illustrate more, the nationality of the third arbitrator must be different from the nationality of the two parties. That applies, unless the parties have agreed on something else. In addition, the arbitrators' place of residence and capacity and other conditions must be taken into consideration when choosing them.

In case the parties didn't agree on the number of arbitrators, the arbitration body shall be consisting from one member. That applies, unless the court finds it necessary to have a three-member arbitration body due to the nature of the dispute. In this case, each party must assign his arbitrator within the specified duration. In case there are several claimants and plaintiffs, the plaintiffs shall assign one arbitrator and the claimants shall assign one arbitrator. That applies in case the arbitration body must be consisting from three arbitrators.

\subsubsection{Formation of Arbitration Body by the Court}

The second method adopted for forming an arbitration body is represented in letting the court form it. This mechanism is adopted in case the arbitration body must be consisting from one member and the parties didn't agree on appointing this member within the specified duration. If the arbitration body consists from 3 arbitrators and none of the parties appointed his arbitrator, the court shall be entitled to appoint the arbitrators on behalf the parties. These cases serve as examples for the cases in which the court is entitled to interfere in assignment of the arbitrator, but are not limited to all such cases. Thus, in case the parties faced a situation that hindered the formation of the arbitration body, the court is entitled to interfere in the formation of arbitration body. That applies even if the situation isn't mentioned in the code of the latter chamber.

The court that the code of the chamber refers to is the International Court of Arbitration. This court is mentioned in article 2 of appendix (a) of the statute of the International Court of Arbitration. The latter article states: (The court consists from the head of the court, members, and replacement members (called members). The court secretariat-general shall assist the court in performing its functions).

The argument above presents the way of forming the arbitration body in the ad hoc arbitration and the institutional arbitration. It sheds a light on a significant arbitration institution; the International Chamber of Commerce. The argument below sheds a light on the conditions of obtaining membership in the arbitration body.

\section{The Conditions of Obtaining Membership in the Arbitration Body}

National legislations and international agreements provided several conditions for obtaining membership in the arbitration body. Under national legislations, some of those conditions may/may not be required by the parties.

\subsection{The Conditions Mentioned in National Legislations and International Agreements}

National legislations -including the Jordanian legislations- and international agreements, ${ }^{8}$ set conditions that

7) If a third party got involved in the dispute and the arbitration body must be a three-member arbitration body, the third party must be involved in the process of assigning the arbitrators along with the claimant(s) and plaintiff(s). The arbitrator named by the third party shall be approved in pursuant to article 13 .

8) The court is entitled to assign all the members of the arbitration body and assign one of those members as the head of the body. That applies in case the parties didn't agree on choosing the arbitrators as it's stipulated through article 12/ paragraphs 6 and 7. It also applies in case the parties didn't agree on the procedures of choosing the members of the arbitration body. In such cases, the court is entitled to choose any person -considered appropriate- as an arbitrator in pursuant to article 13.

${ }^{8}$ The Arab Agreement for Commercial Arbitration of 1987. UNCITRAL model law on international commercial arbitration of 1985. The European agreement on international commercial arbitration of 1961 UNCITRAL arbitration rules of 1976. 
must be met for obtaining membership in an arbitration body. Such conditions include the following:

\section{A. The Number of the Members of the Arbitration Body Must Be Odd}

Article 14/ paragraph 2 of the Jordanian arbitration act states: (In case there must be several members in the arbitration body, the number of those members must be odd. Otherwise, the arbitration process shall be considered void). ${ }^{9}$ Article 5 of the UNCITRAL arbitration rules of 1976 states: "If the parties have not previously agreed on the number of arbitrators (i.e. one or three), and if within fifteen days after the receipt by the respondent of the notice of arbitration the parties have not agreed that there shall be only one arbitrator, three arbitrators shall be appointed". The latter rules were recognized by the United Nations General Assembly. ${ }^{10}$

Based on the legislative texts listed above, the researchers concluded the following:

1) The arbitration body may be consisting from one member or several ones, provided that the number of the members is an odd number

2) The parties have the right to choose the number of members of the arbitration body. However, it must be an odd number.

3) In case the parties didn't reach an agreement on the members of the arbitration body, the legislator enforced provision to regulate this situation. In pursuant to the law, the arbitration body must be consisting from three members (three is an odd number). That's stipulated through article 14 which states: (The arbitration body shall be consisting from one member in pursuant to the parties' agreement. In case the parties didn't reach an agreement on that, the arbitration body shall be consisting from three members).

Thus, when analyzing article 14/ paragraphs 1 and 2, it can be noticed that the parties have the right to choose the number of the members of the arbitration body. That applies provided that the arbitration body shall be consisting from an odd number (e.g. five or seven arbitrators). Despite that, it can be noticed that there are lawse.g. the Spanish law- set a maximum limits for the number of the members of the arbitration body. For instance, under the Spanish law, there shouldn't be more than five members in the arbitration body. The by-laws of British and American organizations (Shafiq, 1976, p. 221); usually require having a one-member arbitration body. That applies, unless the dispute is a major dispute and requires having several members in the arbitration body. The bylaws of organizations in Latin, Germanic and Socialist countries usually require having several members in the arbitration body. For example, article 8 of the bylaw of the International Chamber of Commerce in Paris suggests that the dispute should be settled by one arbitrator or three arbitrators.

Bylaws require having an arbitration body consisting from an odd number of members. That's because one needs to identify the opinion adopted by most of the members. In case the arbitration body consists from an even number, it may be difficult to identify the opinion adopted by most of the members. That's because each opinion may be adopted by an even number of members (Al-Tahyawi, 2003, p. 325). However, article 10 of the Ukrainian Act of International Commercial Arbitration allows the parties to form an arbitration body consisting from an even number of members. In addition, Shariah permits having several members in the arbitration body. It doesn't oblige the parties to have a body consisting from an odd number of members. That is because -under the provisions of Shariah - the arbitral award must be issued based on the consensus of the members of the arbitration body, not based on the opinion adopted by most of the members. Under Shariah, that shall apply, unless the parties agree to something else (Refat, n.p, p. 62). A verse in the Holy Quran states: (If ye fear a breach between them twain, appoint (two) arbiters, one from his family, and the other from hers; if they wish for peace, Allah will cause their reconciliation: For Allah hath full knowledge, and is acquainted with all things). However, what's the consequences resulting from violating the laws that require complying with the "odd number" rule?

The comparative laws -including the Jordanian law- suggest that the consequences resulting from violating the "odd number" rule are represented in considering the arbitration process as being void. Thus, any of the parties can claim before the court that the arbitration process is void (Al-Jamal \& Okashi, 1998, p. 578). In case such claim is filed, no measure can be taken to make the arbitral award valid (Abu Al-Wafa, 1988, p. 160).

Void in this context means that the arbitral award issued by an arbitration body consisting from an even number

\footnotetext{
${ }^{9}$ The same is stipulated through article 15/a of the Egyptian arbitration act of 1994.

${ }^{10}$ Article 15 of the Arab Agreement for Commercial Arbitration states: (The arbitration body must be formed by three members. That applies unless the parties have agreed to something else).
} 
of members shall be considered void. Thus, void in this context doesn't mean that the arbitration agreement is considered void. In case the dispute case is filed to an arbitration body consisting from an even number of members, any of the parties can claim that the arbitration process is void. However, it's not entitled for any party to claim that the arbitration agreement is void.

Despite that, some jurists suggest that the arbitral award issued by an arbitration body consisting from an even number of members is considered valid, provided that the award was issued through obtaining the consensus of the members. In this case, the parties shall not have any reason from claiming that the award is void (Abu Al-Wafa, 1988, p. 172). Article 10 of the Ukrainian Act of International Commercial Arbitration allows the parties to form an arbitration body consisting from an even number of members. The latter article states: (The parties are fully entitled to determine the number of the members of the arbitration body they want). Therefore, this article permits that.

\section{B. The Member of the Arbitration Body Must Be Enjoying Civic Capacity}

Under all the national legislations, the members of the arbitration body must be enjoying full civic capacity. Thus, such members shouldn't be mentally ill, mentally instable, minor, bankrupted, nor deprived from any of their civil rights due to a penal punishment. They shouldn't be deprived from their right to disposal over their properties due to being declared as incompetent by a court judgment.

To illustrate more, minors and mentally ill people can't obtain such membership, because they don't enjoy the right to disposal over their properties due to being legally incompetent. Thus, they can't be responsible for others' rights. Article 15 of the Jordanian arbitration act; ${ }^{11}$ states that minor can't serve as a member of an arbitration body. According to most of the Muslim scholars specialized in jurisdiction, the member of an arbitration body must be adult, and having sound mind and sound senses. It's something logical to require meeting these conditions by judges and arbitrators. Having have sound senses is a condition required by most of the schools of Islamic jurisprudence, except for Al-Maliki school of jurisprudence. Under Al-Maliki school of jurisprudence, it's not required for the arbitrator to have sound senses. In this context, the term (sound senses) refers to having sound sight, hearing and speaking (Refat, n.p, p. 61). It's not permitted for the minor to be a member in the arbitration body, because he is not entitled to concluded a contract by himself nor enjoy the right to disposal over any of his properties. Thus, it's not permitted for minors to be responsible for others' rights (Abed Al-Aleem, 2003, p. 39).

The French jurist; Bernard, criticized the decision to prevent minor from being an arbitrator. That's because Bernard believes that some minors are wiser than the adults. However, the ones who disagree with Bernard state that his view applies to some cases, but not all cases. They also state that legislators enforce laws based on the dominant situation in society. Despite that, it has been permitted for the minor who carries out management and business functions to serve as an arbitrator in disputes related to such functions (Abed Al-Aleem, 2003, p. 39).

It's not permitted for the one who has been deprived from his civil rights to serve as an arbitrator. One may be deprived from such rights due to committing a felony or indecent misdemeanor, such as: theft, abuse of trust, forgery, or honor-related crimes (Al-Jamal \& Okashi, 1998, p. 607). That has been criticized by some people. The one who criticized it claim that there isn't any relationship between the arbitrator's civil status and his arbitration function. They also claim that the membership in the arbitration body is not a public position (Abu Al-Wafa, 1988, p. 160). However, the legislative texts related to capacity in national and international law are binding. International agreements didn't address the issues related to the arbitrator's capacity. However, it's not logical to assign an arbitrator who is a minor, or doesn't enjoy the right to disposal over his properties. It's not logical to assign an arbitrator who is bankrupted or deprived from any of his civil right as a penal punishment, unless his rights have been returned to him (Abed Al-Aleem, 2003, p. 39).

\section{The Arbitrator Mustn't Be One of the Disputed Parties Nor Have An Interest Related To the Dispute}

This condition isn't mentioned in national legislations nor international ones. However, this condition must be met in pursuant to the general rules of litigation. These rules were set through the civil procedures act. This condition is required, because the arbitrator performs a judicial function. This rule is set by many statutory laws. Thus, the parties can't agree to something that violates this rule (Al-Tahyawi, 2003, p. 286). Thus, it's not permitted to let any of the parties serve as an arbitrator. Doing that wouldn't be logical.

It's not permitted to assign an arbitrator who has an interest connected to the dispute. For example, if one of the parties is a moral person, it shall not be permitted to assign the natural person representing that moral person as

\footnotetext{
${ }^{11}$ Article 16 of the Egyptian Arbitration Act.
} 
an arbitrator. That's because this representative has interests connected to this dispute. However, it is permitted to assign any of the employees of the moral person as an arbitrator (Al-Jamal \& Okashi, 1998, p. 607).

It's not permitted to assign an arbitrator who has an interest that is directly connected to the dispute. Thus, it's not permitted for the borrower to serve as an arbitrator responsible for settling disputes between the lender and others. It's not permitted for the guarantor to serve as an arbitrator responsible for settling disputes between the debtor and others. In addition, it not permitted for the partner or the shareholder to serve as an arbitrator responsible for settling disputes between the company he is involved in and others. It's not permitted for the engineer who supervised a certain operations to serve as an arbitrator responsible for settling disputes related to such operations between his employer and the contractor. That is because the engineer served as a supervisor (Abed Al-Aleem, 2003, p. 37).

\section{The Arbitrator Must Be A Natural Person}

The arbitrator is responsible for taking legal procedures and analyzing physical evidence. Thus, he must be a natural person not a moral person. This condition isn't identified by most laws. However, in reality, meeting this condition is definite and obvious. It can be noticed that the Lebanese law is the only Arab law that identifies this condition. For instance, article 786 of the Lebanese civil procedures act states: (The arbitration function can't be assigned to any person who is not a natural person. If the arbitration agreement assigns a moral person, the function of this moral person shall be represented shall in performing organization-related functions).

Thus, through the arbitration agreement, natural persons only can handle the responsibility of settling the dispute. If the parties have agreed to assign the arbitration process to a moral person (such as: the International Chamber of Commerce in Paris), the parties' agreement shall not authorize the moral person to perform the arbitration function. In such a case, the moral person shall be responsible for organizing the arbitration process. In such a case, the moral person shall be responsible for choosing the arbitrators in accordance with the rules of the concerned body (Sami, 1997, p. 154).

\section{E. The Approval of the Arbitrator to Carry out the Arbitration Function. ${ }^{12}$}

When a person is chosen to be an arbitrator, he must provide his approval before initiating his arbitration function. Article 17/ paragraph 3 of the Egyptian arbitration act: (The approval of the arbitrator to carry out the arbitration function must be expressed in writing. The arbitrator must identify any circumstances that may lead to having concerns about his impartiality). This provision is included in the Jordanian arbitration act No. 31 of 2018 enacted the latter provision. However, it is not included in the Jordanian arbitration act of 2001.

Expressing the approval in writing isn't a condition that must be met for considering the arbitration process and its procedures valid. Expressing the approval in writing aims; at avoiding any future dispute that may arise due to the emergence of doubts about the issuance of such approval. The approval of the arbitrator to carry out the arbitration function can be proved through providing tangible evidence. Such evidence may include: sending an invitation sent to the parties by the arbitrator in order to be appear in front of him on a specific date to file their claims, statements of defense and documents. The approval of the arbitrator to carry out the arbitration function can be proved through letting the arbitrator take the conclusive oath. It can be also proved through a confession (Al-Jamal \& Okashi, 1998, p. 594). Thus, the approval of the arbitrator to carry out the arbitration function may be issued implicitly or explicitly (Al-Tahyawi, 2003, p. 332). Based on the general rules of the law, the arbitrator isn't obliged to approve carrying out the arbitration function. However, once the arbitrator approves to carry out the arbitration function, he must accomplish his arbitration mission fully. Otherwise, the arbitrator shall be obliged to pay a compensation for the parties to cover the damages resulting from his failure to accomplish his arbitration mission (Al-Jamal \& Okashi, 1998, p. 594).

The arbitrator may approve carrying out the arbitration function concurrently with concluding the arbitration contract. However, he may approve that after the occurrence of the dispute. In other words, such an approval may be proved in writing through listing that in the arbitration agreement. Another method of proof is represented in the letters exchanged between the members of the arbitration body to discuss dispute-related issues.

When the arbitrator approves to carry out the arbitration function, he must reveal any relationship that may arise concerns about his impartiality. After the arbitrator reveals such relationships, the parties have two choices. The first choice is represented in approving to assign that arbitrator. The second choice is represented in the refusal of any of the parties to assign that arbitrator. In the latter case, the party who assigned that arbitrator must choose

\footnotetext{
${ }^{12}$ It's stipulated through article 265 of the French act, article 234 of the Bahraini arbitration act, and article 259 of the Iraqi arbitration act.
} 
another arbitrator (Al-Tahyawi, 2003, p. 334).

\subsection{Conditions That May/May not be Required for Obtaining Membership in the Arbitration Body}

In the argument above, the researchers provided essential conditions for letting the arbitrator obtain membership in the arbitration body. These conditions are required by most legislations, even if they aren't mentioned explicitly in laws. In short, based on the general rules, the conditions mentioned above must be met by arbitrators. Most legislations recognize the parties' right to enforce their wills. Therefore, the parties are permitted to agree on having specific conditions in this regard. That applies, provided that the parties do not violate national legislations nor international ones. These conditions may include:

\section{A. The Arbitrator's Gender}

Article 15/ paragraph 2 of the Jordanian arbitration act states: (It's not necessary for the arbitrator to be having a specific nationality or to be from a specific gender. That applies, unless the parties have agreed to something other than that or the law states other than that). ${ }^{13}$ It can be noticed that the Jordanian law permits the parties to assign women as arbitrators. Women today enjoy all their constitutional rights, such as: the right to hold a public office. The Jordanian law permits assigning women as arbitrators, because each party is entitled to enforce his will when choosing the arbitrator he trusts. Thus, a party may find a specific woman having all the needed qualifications and expertise for settling the dispute. In such a case, the party's choice is based on qualifications without taking gender into consideration.

Today, women have a significant status in society. For instance, they hold significant public office in countries. Therefore, it wouldn't be fair to allow men only to serve as arbitrators. In short, women should be allowed to serve as arbitrators because they are allowed to hold public office, such as: a judicial positions. Therefore, women are allowed to serve as arbitrators (Al-Tahyawi, 2003, p. 288). Laws of Arab countries and many western countries do not address this issue. As for jurists, they suggest that women are permitted to serve as arbitrators. They base their view on the fact that the selection of arbitrators is based on the party's trust in the arbitrator, and thus, there is nothing that may prevent granting such trust to women (Al-Jamal \& Okashi, 1998, p. 612). In addition, some Muslim scholars specialized in jurisdiction - e.g. the ones adopting Al-Maliki and Al-Hanafi schools of jurisprudence- permitted assigning women as arbitrators. That's because women can provide their testimonies in cases, except in Hudud and Qisas cases (Refat, n.p, p. 62).

Most jurists permit assigning women as arbitrators. However, some jurists and laws don't permit that. Such legislations include: the Greek act that doesn't' permit assigning women as arbitrators (Shafiq, 1970, p. 229). Most of the Muslim scholars specialized in jurisdiction don't permit assigning women as arbitrator nor assigning women in judicial positions. That's because Prophet Mohammad said: (A nation shall not succeed if it's ruled by a women (Refat, n.p, 61)). The modern legislations that don't' permit assigning women as arbitrators base their view on the fact that women aren't permitted to hold public offices. ${ }^{14}$

\section{B. The Arbitrator's Nationality}

Some national legislations suggest that it's permitted to choose arbitrators whose nationality differs from the nationalities of the parties. For instance, article 5/ paragraph 2 of the Jordanian arbitration act states: (It's not necessary to assign an arbitrator from a specific nationality nor a specific gender. That applies unless the parties agreed to something other than that or the law requires doing other than that). According to UNCITRAL model law on international commercial arbitration of 1985, (No one shall be prevented from being assigned as an arbitrator. That applies unless the parties have agreed to something other than that). ${ }^{15}$ The latter law is issued by the United Nations Commission on International Trade Law.

Thus, it can be noticed that the latter article permits providing an arbitration clause that requires assigning foreign arbitrators. It's also permitted to have an arbitration clause that requires delegating the task of assigning arbitrators to a specific foreign institution. That is stipulated through article 24 of the Jordanian arbitration act. The latter article permits the parties to agree on the procedures to be taken by the arbitration body. The latter article permits the parties to agree on enforcing the rules of a specific arbitration center or institution on their dispute. That applies whether the center or the institution is local or foreign.

\footnotetext{
${ }^{13}$ The same is stipulated through article 16/ paragraph 2 of the Egyptian arbitration act. There is nothing about that in the international agreements. Therefore, the parties have the right to choose.

14 The Greek Act, Provided that the arbitrator is a man.

${ }^{15}$ Article 11 of the Model Law. The same is stipulated through article 16 of the Egyptian arbitration act.
} 
Thus, the Jordanian law and the UNCITRAL model law on international commercial arbitration permit assigning a foreign person as an arbitrator. That's because the legislators of these laws believe that being an arbitrator is different than holding a judicial position. Therefore, the arbitration function can be assigned to a foreign body (Hashem, 1991, p. 182). The function of the arbitrator is similar to the function of a judge. However, the arbitrator is not assigned in a public position. That's because the arbitrator's powers are derived from the agreement concluded between the parties. In short, the arbitrators should be enjoying full civic capacity, but it's not necessary for the arbitrators to have a specific nationality.

The jurists who support the latter view base their view on the fact that legislators didn't oblige the parties who have the same nationality to choose arbitrators holding the same nationality. Therefore, the latter jurists believe that in case the parties' nationalities differ from each other, there is nothing that prevents requiring to assign an arbitrator who has a nationality similar to the nationality of any of the parties. Due to the parties' right to enforce their wills, the parties are entitled to form an arbitration body that consists from foreigners or includes some foreigners. That applies unless there is an agreement that prohibits the parties from doing that (Al-Tahyawi, 2003, p. 292). Some parties prefer assigning foreigners as arbitrators, because they believe that foreigners have more expertise than local arbitrators in the arbitration field.

However, some jurists, ${ }^{16}$ believe that the members of the arbitration body must be enjoying their political rights. Therefore, they believe that it's not permitted to assign foreigners as arbitrators. They base their view on the fact that the arbitration function is a judicial function. Therefore, judicial functions shouldn't be assigned to foreigners. The latter jurists base their view on the fact that arbitrators are granted a public authority and thus, arbitrators must be enjoying civic capacity, and eligible to hold a political position.

There is a third view. For instance, some international agreements related to international commercial arbitration require assigning an arbitrator holding a nationality that is different from the parties' nationalities. Under such agreements, it's not permitted to assign an arbitrator who holds a nationality that is similar to the nationality of any of the parties (Al-Tahyawi, 2003, p. 300). For example, article 18/ paragraph 4 of the Arab Agreement for Commercial Arbitration requires so. The latter paragraph states: (It's not permitted to assign arbitrators who hold a nationality that is similar to the nationality of any of the parties). Under article 9/ paragraph 5 of the amended code of the International Chamber of Commerce in Paris, the arbitrator in a single-member arbitration body must be holding a nationality that is different from the parties' nationalities. Under the latter paragraph, the same applies to the head of the arbitration body.

From the perspective of the researchers of this study, the legislative texts provide a general rule. To be specific, the legislator didn't address in details the issues related to the arbitrator's nationality. In short, he allowed the parties to reach an agreement on the arbitrator's nationality. However, the parties must take into consideration the ratification of the Arab Agreement for Commercial Arbitration by the Jordanian government. The latter agreement obliges the parties to choose an arbitrator holding a nationality that is different from the parties' nationalities. That applies in case the parties agreed to seek arbitration in pursuant to the latter agreement. The latter agreement has priority over the national law.

\section{The Expertise of the Arbitrators}

Most of the national legislations don't address the expertise of the arbitrators. Thus, the parties are permitted to choose arbitrators of any expertise. For instance, they are entitled to choose arbitrators possessing technical expertise. They are also entitled to choose arbitrators who don't possess such expertise. Jurists provided views about this matter under discretion. Some jurists believe that arbitrators must have much expertise and other jurists don't believe so.

The jurists adopting the first view believe that arbitrators must have much expertise. According to these jurists, if arbitrators are not specialized in law, they must be specialized in the area related to the dispute. According to these jurists, arbitrators may be engineers, economics, or farmers. The latter jurists base their view on the fact that assigning arbitrators specialized in the area related to the dispute shall accelerate the process of settling the dispute without consulting experts (Al-Jamal \& Okashi, 1998, p.613). The Saudi legislator adopted this view. For instance, article 4 of the Saudi law states: (The arbitrator must possess much expertise and have a record indicating that he has a good conduct).

The jurists adopting the second view believe that it's not necessary for arbitrators to be specialized in law, nor having much expertise in the area related to the dispute. They base their view on the fact that the parties entrust the arbitrators they have chosen. Thus, that means that the parties believe that the chosen arbitrators are capable

${ }^{16}$ Like Garsonnet. (Cited from Al-Tahyawi, ibid.,p.292). 
of settling the dispute regardless of their expertise (Al-Tahyawi, 2003, p. 308).

The Jordanian law doesn't include any legislative text indicating that the arbitrators must be having much expertise. However, the researchers of this study believe that arbitrators must be having much expertise. They believe so, because assigning an arbitrator who doesn't have expertise in the law field or in the field related to the dispute shall hinder the process of settling the dispute and deaccelerate the litigation procedures. However, arbitration is usually sought by parties, because they want to accelerate the litigation procedures and settle the dispute fast.

\section{The Permissibility of Assigning the Judge As An Arbitrator}

Statutory laws and international agreements permitted parties to assign a judge as an arbitrator. Thus, parties are entitled to assign the chief justice as an arbitrator. However, there is a debate among jurists about this matter. For instance, some jurists permits assigning the judge as an arbitrator, whereas other judges don't permit that. The jurists permitting that base their view on the fact that parties are permitted to assign engineers as arbitrators. Therefore, there is no reason that prevents assigning the judge as an arbitrator (Al-Tahyawi, 2003, p. 303). The French judiciary permitted assigning an Algerian judge as an arbitrator between the disputed parties. It declared that the arbitral award issued by the latter arbitrator shall serve as a court judgement that no appeal can be filed against it.

The second view suggests that it's not permitted to assign a judge as an arbitrator. The researchers of this study support the latter view. That's because assigning the judge as an arbitrator shall negatively affect the performance of the judge at the judiciary due to being busy in performing the arbitration-related functions. The researchers support the latter view, because that may affect the impartiality of the arbitrator. That's because the wage paid for arbitrators are much higher than the wages paid for judges. Thus, the arbitrator's award may be biased for the favor of the powerful and rich party. ${ }^{17}$

Article 17 of the Jordanian judicial independence law No. 29 of 2014 states: (It's permitted to assign the judge as an arbitrator based on a request by the Council of Ministers. That applies if the judge is assigned as an arbitrator by the latter council. It applies in case the government or any public body is one of the disputed parties, and the dispute is an international dispute. The latter council shall determine the wage of the arbitrator in this case). Under the latter article, it can be found that the judge can serve as an arbitrator in specific cases. However, that must be approved by the Council of Ministers. Under the latter article, the general rules in the law suggest that it's not permitted for the judge to be an arbitrator, except in specific cases.

\section{E. The arbitrator must be literate:}

National legislations and international agreements do not address the issues related to the literacy of the arbitrator. They permitted the parties to choose literate and illiterate arbitrators. Several jurists addressed the issues related to the literacy of the arbitrators. In this regard, there are two views adopted by jurists in this regard.

The first view suggests that it's permitted to assign illiterate people as arbitrators. The latter views suggest that it's permitted to assign an illiterate person as an arbitrator in a single-member arbitration body. It also suggests that it's permitted to have an arbitration body whose all members are illiterate. However, in the latter case, an employee must be assigned for handling the tasks related to reading and writing. He must be assigned for writing the arbitral award and do the paper works needed for initiating the arbitration process. The latter views suggests that it's permitted to assign arbitrators who do not speak the language spoken by the disputed parties. In the latter case, the arbitrators shall issue the arbitral award based on the translated documents submitted to them (Abu Al-Wafa, 1988, p. 155). The jurists who support the latter view base their view on the following:

1) Under statutory law, it's required to write and sign the arbitral award by the members of the arbitration body. However, that doesn't mean that the arbitrators must be literate.

2) If the arbitrator is illiterate, a person may be assigned to do the writing tasks. That applies even if the arbitration body is a single-member arbitration body.

3) An illiterate person may be assigned as an arbitrator, because the parties may entrust him and he possesses more technical expertise than a literate person. It should be noted that parties choose arbitrators, because they believe that those arbitrators have expertise and capabilities that enable them to settle the dispute even if they are illiterate (Al-Tahyawi, 2003, p. 305).

\footnotetext{
${ }^{17}$ The ones supporting this view include: Mohammad Abed Al-Khaleq Omar through his book; the civil judicial system. Dr. Muhsen Shafiq adds that assigning the judge as an arbitrator isn't valid. That's because the request to approve assigning a specific arbitrator or consider the assignment of an arbitrator as void should be filed to the judge. Thus, that leads to the overlap of powers. Shafiq, ibid., p. 229.
} 
The second view adopted by jurists suggests that the arbitrator must be literate. The latter jurists base their view on the fact that the arbitrator's function requires having a person who is capable of reading the parties' documents and writing and signing the arbitral award. In addition, performing the arbitrator's function requires having a person who is capable of writing the reasons that he based his arbitral award on. The latter jurists base their view on the fact that the arbitrator must be acquainted with the relevant laws and rules and other matters and such acquaintance requires having someone literate to read about such things. According to the latter jurists, laws don't set this condition because it's something obvious and definite that doesn't need having a legislative text (Al-Jamal \& Okashi, 1998, p. 613).

The researchers of the present study believe that arbitrators must be literate. That's because assigning a literate arbitrator shall accelerate the arbitration procedures. However, the researchers believe that assigning an illiterate arbitrator shall not have a major negative impact on the arbitration process. That's because the parties have the right to enforce their wills. For instance, a party may assign a certain illiterate person as an arbitrator, because this person is more capable than others to settle the dispute.

\section{F. Taking the oath:}

The Jordanian arbitration act doesn't include this condition. However, some international agreements include this condition. Under these agreements, the arbitrator must take the oath before he initiates his arbitration mission. Such agreements include the Arab Agreement for Commercial Arbitration of 1985. The latter agreement includes the following statement: (Before the arbitrator initiates his arbitration mission, he must take the oath before the head of the center or the deputy head of the center. Through this oath, the arbitrator must swear by Allah that he shall enforce justice, comply with the applicable law and perform his function with showing integrity and fairness). ${ }^{18}$

\section{G. The Arbitrator's Religion}

Most of the national legislations -including the Jordanian legislations- don't set conditions related to the arbitrator's religion. However, some legislation provide the opposite. For example, under the Saudi arbitration act, the chosen arbitrator must be Muslim. Under article 3 of the Saudi act, the chosen arbitrator must be one of the Muslim foreigners or Muslim locals. Based on the latter article, it was found that the Saudi government permitted the disputed parties to choose an arbitrator from the locals or foreigners, provided that the chosen arbitrator is Muslim (Refat, n.p, p. 93).

\section{The Judicial Control Enforced over the Formation of an Arbitration Body}

The dominant method for settling disputes is represented in going to court. However, the state permitted people to seek arbitration in order to save time and effort. However, arbitration is considered very costly. People seek arbitration to avoid going to court. The legislator permitted the disputed parties to choose their arbitrators, set the suitable rules of choosing arbitrators and identify the procedures to be followed. He permitted the parties to choose the language to be used for taking the procedures and the place at which the arbitration shall be conducted at. The arbitrator shall settle the dispute and issue an arbitral award instead of having a judge issuing a judgment to settle the case. The arbitral award shall eliminate the need to issue as a judgment by court. Governments recognize the arbitration process as a substitute for the litigation process conducted by the court. However, it recognizes the functions of judiciary too. The latter functions serve as manifestations of the state's sovereignty. Therefore, the legislator took measures for ensuring that arbitrators shall be impartial. Such measures include enforcing judicial control over the formation and dismissal of arbitrators. Thus, this study sheds a light on the role of the judiciary in enforcing judicial control over the process of assigning arbitrators (section one). It sheds a light on the dismissal of the arbitrator and the consideration of their assignment as void when having concerns about his impartiality and integrity (section two).

\subsection{The Role of the Judiciary in Assigning Arbitrators and the Court That Has Jurisdiction}

In case the parties didn't implement the agreed upon mechanism of forming the arbitration body, article 16 of the Jordanian arbitration act provides a solution for this case. The cases mentioned in article 16 are few cases, but are not limited to all cases. In case the arbitrator(s) was/were not chosen for a reason other than the ones mentioned in article 16, any of the parties can request the court that has jurisdiction to choose the arbitrator(s).

The court mentioned in article 16 is the court of appeal. Article (2) of the Jordanian arbitration act states: (The court that has jurisdiction is the court of appeal. It has jurisdiction over the arbitration process, unless the parties agreed to choose another court of appeal).

\footnotetext{
${ }^{18}$ Article 14 of the Arab Agreement for Commercial Arbitration.
} 
There are conditions regulating the interference of the court in the arbitration process. These conditions are: 1)If the arbitration agreement is in the original contract, the court shall interfere after the occurrence of the dispute (Al-Jamal \& Okashi, 1998, p. 590). ${ }^{19}$ 2)-If an arbitration agreement is concluded after the occurrence of the dispute and a disagreement occurred on choosing arbitrators or the mechanism of choosing them, the court can interfere upon request (Al-Tahyawi, 2003, p. 436). Thus, the Jordanian legislator identifies several cases in which the court can interfere in choosing arbitrators. These cases are:

First: This case is represented in having a disagreement between the parties on choosing the member of the single-member arbitration body. Under article 16/a/1 of the Jordanian arbitration act, in case the parties didn't reach an agreement on choosing the arbitrator, and the arbitration body must be consisting from one member, the judge who has jurisdiction shall be responsible for choosing the arbitrator. That occurs upon the request of any of the parties. ${ }^{20}$ Based on article 2 of the arbitration act, the (judge who has jurisdiction) in this context refers to the head of the court that has jurisdiction or the one delegated by the court that has jurisdiction. In this regard, the Jordanian court of cassation issued judgment No. 2019/3249 on 19/6/2019. This judgment states: "The court finds that the appealed decision is issued by the court of appeal in Ma'an. However, articles 2 and 16 of the amended arbitration act No.16 of 2018 suggest that the request of assigning arbitrator(s) must be filed to the judge who has jurisdiction (i.e. the head of the court of the appeal or the one delegated by the court of appeal). Thus, the decision issued by the court of cassation is considered a void decision. It is considered issued by a court that doesn't have jurisdiction". This case is presumed in case the parties have already agreed explicitly on forming a single-member arbitration body. In case the parties didn't reach an agreement on the number of the members of the arbitration body, this body shall be consisting from three members by the force of the law. That's mentioned in article 14 of the arbitration act. This case is presumed in case the parties didn't reach an agreement on choosing the member of the single-member arbitration body or the way of choosing this member. In case the parties agreed on implementing a specific mechanism for choosing the arbitrator, they can't go to court unless they have failed in implementing this mechanism (Al-Jamal \& Okashi, 1998, p. 59).

Second: This case is represented in having a party refraining from assigning his arbitrator within the 15 days following the day on which he received a request in this regard by the other party. That's stipulated through article $16 / \mathrm{A} / 2$ of the Jordanian arbitration act. ${ }^{21}$ This case is presumed when the arbitration body must be consisting from three members or more, and no agreement were reached on the name or position of those members and the mechanism of choosing them. This case can be presumed in case the parties agreed or didn't agree on the number of the members of the arbitration body. In case the parties didn't reach an agreement on such a number, the body shall be consisting from three members by the force of the law.

If the arbitration body consists from three members, each party must choose one arbitrator. If the members of the arbitration body are more than three, each party must choose half of the body. In case one of the parties didn't assign his arbitrator(s) within the 15 days following the day on which he received the request in this regard by the other party, the other party is entitled to request the judge to assign an arbitrator on behalf of the refraining party.

Under the latter article, the refraining party must be notified. In case a request was filed to the judge within the 15 days following the day on which the notification was received, it shall be considered a request submitted before the due time. In this regard, the Jordanian court of cassation issued judgment No. 2019/2762 on 195/2019. The latter judgment states: (The documents attached to the request don't include a notification or a request sent by the claimant to the plaintiff. It was found that an arbitrator was assigned on behalf of the plaintiff. It was found that the claimant has already assigned his arbitrator. It was found that there is no proof indicating that a disagreement has occurred between the parties about the way of choosing the arbitrators. Under article 16/b of the arbitration act, the court of appeal committed a mistake in enforcing and interpreting the law. That's because the latter court decided to assign an arbitrator on behalf of the plaintiff before the due time).

Third: This case is represented in having a disagreement between the two arbitrators -assigned by the partieson assigning the third arbitrator who shall head the arbitration body. That applies provided that 15 days have passed following the date on which the last arbitrator was assigned on. That's stipulated through article 16/a/2 of the Jordanian arbitration act. ${ }^{22}$ This case is presumed in case each party has assigned his arbitrator, but the two

\footnotetext{
19 There may be an implicit agreement to postpone choosing the arbitrator till the occurrence occurs. That's because the parties consider the occurrence of dispute is not define and thus, there's no need for choosing arbitrators in advance.

${ }^{20}$ Article 16/a/1 of the Jordanian arbitration act. Article 17/1/a of the Egyptian arbitration act. Article 11/3/b of UNCITRAL law.

${ }^{21}$ Article 17/1/b and article 13/1/a of UNCITRAL law.

22 The same is stipulated through article 17/B of the Egyptian act and article 11/3/1 of UNCITRAL law.
} 
selected arbitrators didn't reach an agreement on assigning the third arbitrator. In the latter case, none of the parties separately nor both parties mutually are entitled to assign the third arbitrator. Otherwise, such an assignment shall be considered void. In the latter case, both parties jointly, or one of them separately can ask the judge who has jurisdiction to assign the third arbitrator. Such a request can be filed, provided that 15 days have passed following the date on which the last arbitrator was assigned on.

Fourth: This case is presumed in case one of the parties may violate the agreed upon procedure of assigning the members of the arbitration body. It can be also presumed in case the parties didn't reach an agreement on such procedure. Such cases are mentioned in article $16 / \mathrm{G}$ of the Jordanian arbitration act. ${ }^{23}$ In any of these cases, none of the parties is entitled to choose the members of the arbitration body by himself only. Otherwise, the arbitration process shall be considered void. In any of those cases, any of the parties must request the judge who has jurisdiction to assign the members of the arbitration body.

Fifth: The delegated person may fail to assign the member of the single-member arbitration body or the head of the arbitration body within the specified duration. Under article $16 / \mathrm{C}$ of the arbitration act, ${ }^{24}$ in this case, any of the parties shall be entitled to request the judge who has jurisdiction to assign the member of the single-member arbitration body or the head of the arbitration body (in case the body consists from 3 members of more). When the court interferes in choosing the arbitrator(s), it must meet the conditions set by the law and the parties. When such interference occurs, the court must choose the arbitrators fast as it's stipulated through article 16/G of the arbitration act.

Sixth: The parties may reach an agreement on the number of the members of the arbitration body and the way of choosing them, without reaching an agreement on the way of choosing the head of the arbitration body. In this case, the head shall be chosen through the consensus of the members of the arbitration body. In case the members failed to do that, the judge who has jurisdiction shall be responsible for choosing the head upon the request of any of the parties. That applies in pursuant to (article 16/b/1 of the Jordanian arbitration act). Unlike the third case, in the sixth case, the parties didn't reach an agreement on the way of choosing the head of the arbitration body. In the third case, the parties have reached an agreement on the way of choosing the head of the body, but the chosen arbitrators failed to choose the head.

Seventh: The parties may have reached an agreement on the number of the members of the arbitration body, but didn't reach an agreement on the mechanism of choosing these members. In the latter case, the judge who has jurisdiction shall be responsible for choosing these members and the head of the body.

In case the parties didn't reach an agreement on the number of the members of the arbitration body nor the way of choosing these members, the body shall be consisting from three members by the force of the law. In the latter case, the judge who has jurisdiction shall be responsible for choosing the members of the body and the head of the body. That's stipulated through article $16 / \mathrm{b} / 2+3$ of the Jordanian arbitration act. When choosing the arbitrators by the judge, the judge must take into consideration the conditions and qualifications required by the law and the parties mutually.

Eighth: This case isn't mentioned in the Jordanian arbitration act, but may occur in reality. It's mentioned in the code of the International Chamber of Commerce. This case is represented in having several claimants or several plaintiffs. Under the latter code, in such a case, the claimants or the plaintiffs must choose mutually chose their arbitrator(s).

In case there are three claimants and there is an agreement on forming a three-member arbitration body, the claimants must choose one arbitrator mutually. In case the claimants failed to do that, they or the plaintiff(s) can request the judge who has jurisdiction to assign an arbitrator

\subsection{The Role of the Judiciary in Dismissing Arbitrator(s) and Considering Their Assignment as Void}

Through the above argument, the researchers present the cases in which the parties do not choose the arbitrator(s) and thus, the court interferes in making such choice. The court interferes in that to ensure that the arbitration process shall be conducted effectively. However, what's the role of the judicial control in case arbitrators were assigned, but there are concerns about the impartiality and integrity of these arbitrators? In this regard, it should be noted that the impartiality and integrity of these arbitrators shall affect the arbitral award. According to the Jordanian legislator, in case there are such concerns, the arbitrator(s) may be dismissed or their assignment shall

\footnotetext{
${ }^{23}$ The same is stipulated through article 17/2 of the Egyptian arbitration act and article 11/4/g of UNCITRAL law.

${ }^{24}$ The same is stipulated through article $17 / 2$ of the Egyptian arbitration act and article 11/4/g of UNCITRAL law. The delegated person may be a natural person who's identified in name or position. He may be moral person.
} 
be considered void.

First: The role of the judiciary in considering the assignment of the arbitrator as void. The arbitrator's assignment may be considered void because any of the parties may suggest that he doesn't want to have a specific person as a member in the arbitration body due to having of any of the reasons mentioned in articles 17-20 of the Jordanian arbitration act. Under the Jordanian laws the arbitrator's assignment may be considered void due to reasons related to his impartiality and integrity and thus, the arbitrator shall be deprived from this power (Ibrahim, 1995, p. 140). The Jordanian legislator granted the parties and the court discretionary power in terms of determining the reasons requiring to consider the assignment of the arbitrator as void. He permitted considering the assignment of the arbitrator as void for any reason related to the arbitrator's impartiality and integrity. However, he set several controls regulating the process of requesting to consider the assignment of the arbitrator as void. These controls are set to avoid filing such a request in the aim of decelerating the arbitration process.

Article 17 of the arbitration act suggests: (It's not permitted to file a request for considering the assignment of the arbitrator as void, unless there are reasons related to the arbitrator's impartiality and integrity. None of the parties is entitled to file such a request against the arbitrator he assigned or participated in making the decision of assigning him, unless reason(s) justifying filing such request was/were acknowledged after making such assignment).

Through the civil procedures act, the Jordanian legislator regulated the request for considering the assignment of the judge as void through enacting rigid legislative texts. However, the Jordanian legislator regulated the request for considering the assignment of arbitrator as void by enacting flexible legislative texts. In fact, he granted much discretionary power to the court entitled to assess the reasons related to the arbitrator's impartiality and integrity (Abu Sharbi, 2014, p. 61). Under article 18 of the civil procedures act, the request of considering the assignment as void must be submitted in writing to the court that has jurisdiction with identifying the reasons for making such a request. This request must be filed within 15 day following the date on which the party acknowledged the reasons justifying the request. In case the arbitrator didn't resign from his position willingly, the court shall issue a decision upon submitting this request. No appeal can be filed against such a decision.

Under article 18/c of the arbitration act, filing such a request shall not deaccelerate nor hinder the arbitration procedures. In fact, the concerned arbitrator should continue carrying out such procedures until issuing the suitable decision. In case such a request was rejected, the arbitration procedures taken while the arbitrator was a member shall be considered valid. In case such a request was approved, the arbitration procedures taken while the arbitrator was a member shall be considered invalid. Such procedures shall be taken again after assigning another arbitrator by the same party.

Second: The role of the judiciary in dismissing the arbitrator. Article 19 of the Jordanian arbitration act states: (The arbitrator may fail to do or initiate his arbitration function or stop performing this function in a manner that leads to hindering the arbitration procedures without any justification. In case that occurred and the arbitrator didn't resign willingly nor the parties agreed to dismiss him jointly, the court is entitled to dismiss him upon the request of any of the parties. No appeal can be filed against the dismissal decision issued by the court). The dismissal may occur before the arbitrator hears the case. It may occur after the arbitrator hears the case and before issuing the arbitral award. It may occur after issuing the arbitral award. Under the latter article, the court is entitled to dismiss the arbitrator in accordance with specific conditions and measures. Under this article, the court's decision to dismiss the arbitrator can't be appealed. The reasons behind such dismissal may be legal reasons. Such legal reasons may include: having a judgment that deprives the arbitrator from his right to disposal over any of his properties due to being mentally ill. Such reasons include having a judgment that deprives the arbitrator from his civil rights. Such reasons include experiencing a chronic disease that hinders the arbitrator from practicing his function. Such reasons include stopping from performing the arbitration function without providing any justification.

Once the arbitrator is dismissed, another one must be assigned to take his place. That should be done in accordance with the procedures taken in such a case. The arbitrator may be dismissed based on the parties' request. That applies in case the arbitrator became incapable to do his arbitration function due to becoming sick, death, or losing capacity. Based on the aforementioned, it can be noticed that the judicial interference in the formation of an arbitration body includes: interference in the assignment and dismissal of the arbitrator and considering the assignment of the arbitrator as void. Such interference aims at ensuring that the arbitral awards are unbiased and impartial.

\section{Conclusion}


There is much criticism against arbitration due to the high cost incurred by the disputed parties. However, the number of the ones seeking arbitration has been increasing. That's because parties want to avoid going to court to settle their dispute. Therefore, arbitration has been receiving increasing attention. There are also legislative texts that regulate arbitration. However, such texts overlook some issues.

There are several national legislations and international legislations that aim at regulating arbitration. These legislations regulate the formation of the arbitration body and the conditions of obtaining membership in the arbitration body. There is also a judicial control enforced on the arbitration process in order to ensure that the arbitral awards are unbiased and impartial. The researchers concluded the following results:

1) The legislator provided mechanisms for choosing the arbitrators and forming the arbitration body. That applies to the ad hoc arbitration and the institutional arbitration.

2) The Jordanian legislator granted the disputed parties the right to choose the arbitrator and form the arbitration body. However, the parties must meet the conditions set by the legislator or the parties. They must comply with the selection standards mentioned in the law.

3) The Jordanian legislator provided much attention to the arbitration process. For instance, he enacted legislative texts regulating the process of forming the arbitration body. He entitled the judiciary to interfere in the process of assigning the arbitrator to ensure that the arbitral awards shall be unbiased, impartial and implemented.

4) Under the arbitration act, the court of appeal is the one entitled to examine the request of considering the assignment of the arbitrator as void and the request for the dismissal of the arbitrator. It's granted such power to avoid having an appeal filed against the decision of the court in this regard.

5) The Jordanian legislator didn't identify the reasons in specific behind the dismissal of arbitrators. He granted discretionary power to the court to assess the provided reasons and take the suitable decisions.

In conclusion, and in the light of these results, the researchers recommend the following recommendations:

1) The researchers recommend amending the legislative texts listed in the arbitration act which concern the formation of the arbitration body. That should be done to identify -in details- the extent and limits of the judicial control enforced on the arbitration body and the powers granted to the court in this regard.

2) The researchers recommend amending the legislative texts listed in the arbitration act which concern considering the assignment of the arbitrator as void and the dismissal of the arbitrator. For instance, the law must identify in specific the reasons and procedures of filing a request for dismissing arbitrators and the request for considering their assignment as void. That should be done to avoid filing such requests in the aim of hindering the arbitration procedures.

3) The Jordanian legislator must adopt the approach adopted by the one who enacted the code of the International Chamber of Commerce. To be specific, he must enact a legislative text that regulates the arbitration cases that include several plaintiffs and/or claimants. He must identify the impact of that on the formation of an arbitration body. Such a text may state: (If there are several claimants and plaintiffs and the arbitration body must be consisting from three members, the claimants shall mutually choose one arbitrator and the plaintiffs shall mutually choose one arbitrator. The selected arbitrators shall choose the third arbitrator who shall head the body).

4) If there are two disputed parties and a third party got involved in the dispute, the third party must get involved in the process of assigning the arbitrators. There must be a legislative text regulating that. Such a text may state: (If a third party got involved in the dispute and the arbitration body must be consisting from three members, the third party must be involved in the process of assigning arbitrators in along with the claimant(s) and plaintiff(s).

\section{References}

Abed Al-Aleem, A. (2003). The Public Order and the Law Applicable to the Arbitration Procedures in the Relationship Including a Foreign Part. Alexandria: Al-Feker Al-Jame'y Publishing house.

Abu Al-Wafa, A. (1988). Commercial Arbitration. Alexandria: Al-Ma'aref Publishing House.

Abu Sharbi, T. (2014). The Legal Effects of Requesting to Consider The Assignment of The Arbitrator As Void. (Unpublished master dissertation). University of The Middle East University, Amman, Jordan.

Al-Dahleh. H. (2002). The arbitral award under the arbitration act No. 31 of 2001, The Journal of Jordanian Bar Association, 2(5). 
Al-Jamal. M., \& Okashi, A. (1998). Arbitration In International and National Relationships (1st part, 1st ed.). Beirut: Al-Halabi Publications In Law.

Al-Mu'nes, H. (1977). Al-Wajeez for Arbitration. Beirut: Al-Nahda Al-Arabeya publishing house.

Al-Nesa'i. (1964). Literature About Judges. Part No.8. Damascus: Mustafa Al-Halabi Bookshop.

Al-Tahyawi, M. (2003). The Personal Element of the Arbitration Place. Alexandria: Al-Feker Al-Jame'y Publishing House.

Al-Zayla'i. (1315). Illustration of Facts. Illustration of the Treasure of Minutes. Cairo: Al-Kubra Al-Mereye Printing House.

Hashem, M. (1991). The General Theory of Arbitration in Pursuant to Civil and Commercial Legislative Texts. Alexandira: Al-Feker Al-Arabi Publishing House.

Ibrahim, A. (1995). The Control of The Judiciary Over Arbitration. (Unpublished doctoral dissertation). Ain Shams University, Cairo, Egypt.

Madkour, M. (1999). Intrdouction to Fiqh (4th ed.). Cairo: Al-Nahda Al-Arabeya publishing house.

Muneer, A. (1995). Arbitration in International Commercial Disputes. Alexandria: Al-Matbuat Al-Jame'ye Publishing House.

Refat, W. (n.p). International and National Commercial Arbitration in the Kingdom of Saudi Arabia. Jeddah: The Chamber of industry and commerce.

Sami, F. (1997). International commercial arbitration. Amman: Al-Thaqafa Publishing House.

Shafiq, M. (1970). International commercial arbitration. Cairo: Al-Nahda Al-Arabeya publishing house.

\section{Copyrights}

Copyright for this article is retained by the author(s), with first publication rights granted to the journal.

This is an open-access article distributed under the terms and conditions of the Creative Commons Attribution license (http://creativecommons.org/licenses/by/4.0/). 